\title{
Editorial
}

\section{THINKING ABOUT ELECTIONS AND ABOUT DEMOCRATIC REPRESENTATION}

Representation is no doubt the richest power of human intelligence. It stretches across the realms of understanding and creation, of thought and expression, sitting at the heart of art, law, commerce, science, politics. In each of these, representation is meant to give expression to ideas, interests, moods, and thus to lift them from the implicit and subjective to the explicit and objective.

Of all its versions, political representation is the one to have appeared latest, in the Middle Ages. It is the basis of modern representative democracy. Older and less sophisticated forms, such as direct democracy, subsist marginally, even if they keep exerting a certain attraction. But representative democracy does not carry the self-evident authority it once had. Like every modern institution it is under challenge and consequently needs to be defended. In actual politics, the defence often takes the form of discussion of the merits of one system over the other and of proposals for change. The part of this defence appertaining to constitutional scholarship is not concerned primarily with proposals and changes. It is, before all, to brush up the fundamentals underlying representative democracy, on the basis of topical issues.

There are three current issues upon which we would like to draw attention. They are: equality in structuring electoral systems, the processes of electoral reform and the rise of non-majoritarian institutions versus parliamentary democracy.

The issue of electoral equality as the foundation of elections and of representation has been tabled by the German Federal Constitutional Court in its ruling on the Lisbon Treaty. The Court held that the European Parliament could not be considered a popular representative body on a par with national bodies, as it is constituted according to the principle of regressive proportionality. ${ }^{1}$

In its simplicity, this challenge is formidable, and it needs to be answered by scholarship. Prima facie indeed, the inequality between European citizens of different countries in the election for the European Parliament is so manifest and

${ }^{1}$ BVerfG 123, 267 (2009).

European Constitutional Law Review, 7: 1-3, 2011

(C) $2011 \mathrm{~T} \cdot M \cdot C \cdot A$ ASER PRESS and Contributors

doi:10.1017/S1574019611100012 
massive, that it seems to disqualify the European Parliament almost as a matter of principle.

At the same time this disqualification amounts to a denial of reality. Even if the democratic and representative credentials of the European Parliament is no way near the level of most of the popular representative institutions in the member states, it is difficult to say that the European Parliament is disqualified as a matter of principle. The Bundesverfassungsgericht may be right to note a flaw in the EP's representative basis, and it may even be right in noting a certain weakness in its actual representative capacity. But to turn a formal criterion against the very possibility of a development of practice is no doubt taking legal reasoning too far into the field of political reality.

Saying that does not, however, settle the matter from the angle of scholarship. To prove the Bundesverfassungsgericht wrong also in the matter of theory and principle, one needs to pick up the challenge by showing in what way the European Parliament, even on an unequal basis, can nevertheless be considered a popular representative institution. This means digging below the formal principle of equality and possibly even rethinking political representation in a non-state context. It is a fascinating project and it needs to be undertaken.

A second issue is that of the rules by which elections take place. Electoral systems are not static, they are subject to evolution. This evolution is usually under the close supervision of elected politicians themselves. The French change from a majoritarian to a proportional electoral system (and back) in the 1980s springs to mind. A common example of politicians' impact on electoral rules relates to disputes in drawing the borders of constituencies - better known as gerrymandering - which are not uncommon in the United Kingdom or United States. In the United Kingdom, the Labour Party has accused the coalition of Conservatives and Liberal Democrats that the coalition's plans to reduce the membership of the House of Commons and simultaneously re-draw electoral boundaries to achieve greater parity in constituency size would benefit the Tories disproportionately. Solace in the face of political manipulation of the electoral process might be sought in turning to the courts, we hear you say. After all, was it not the courts that ruled on the legality of electoral reform in France and the Czech Republic in recent years? ${ }^{2}$ And, might the final word not be given to the electorate in deciding if a particular system is to be changed, such as in the British referendum on electoral change, this 5 May?

At the same time the Belgian political establishment has been frustrating the execution of the Constitutional Court's ruling that the contested district of

\footnotetext{
${ }^{2}$ French Conseil Constitutionnel, judgment no. 2008-573 DC; Czech Constitutional Court, judgment no. 64/2001 Coll.
} 
Brussels-Halle-Vilvoorde is to be split. ${ }^{3}$ And in the UK, the framing of the question for the referendum might not be irrelevant to the result. There is no escaping from having the political establishment at the helm of electoral change. This is a strongly limiting factor, but it does not block evolution totally. Of course we need to consider the various factors and their possible consequences and motives in what might seem to be a natural evolution of electoral systems. On the other hand, as elections themselves are meant to express the need of change and the wish of a certain direction, so are, in a second degree, electoral systems. In an open society, no one has a monopoly on change, nor full control of its channels.

For European constitutional scholarship, the developments in electoral systems can only have one thing to say: the subject of electoral systems and their change is full of great questions and could do with some more attention. In the USA, electoral law has carved out a comfortable niche for itself under the broad constitutional umbrella. An alliance with political science has been quite fruitful there; it could be the same in Europe. ${ }^{4}$

Last but not least, inquiring minds should also be directed at studying the relationship between majoritarian and non-majoritarian decision-making structures. Long gone is the French Revolution and its emphasis on the sovereign will of the people and with it a deep distrust of non-majoritarian decision-making, such as the courts which were tainted by the ancien régime. In marked contrast, the Second World War ushered in an age of trust in the wisdom of judiciaries and non-political or counter-majoritarian institutions. This trust often goes over and above representative structures such as parliaments and governments. The idea behind these agencies is to increase effective and unbiased governance by removing them from the politically-charged influence of the elected, majority-based government. However, what is the normative value of this state of affairs, today? Has this shift from faith in majorities to other conceptions of power gone too far? What are the consequences of removing voters from the actual levers of power in modern society? For stimulating thought on these problems we leave our readers in the capable hands of Cesare Pinelli, who further develops them in his contribution to this issue.

LH, GvdS, WTE

\footnotetext{
${ }^{3}$ Belgian Constitutional Court, judgment no. 2003-073.

${ }^{4}$ See Heather Gerken, 'What Election Law Has to Say to Constitutional Law', available at http://ssrn.com/abstract=1619882
} 